\title{
Sustainable development by Sahara Solar Breeder plan: Energy from the desert of Algeria, a Green Energy Dream grows in the Sahara
}

\author{
A. Boudghene Stambouli ${ }^{1}$, H. Koinuma ${ }^{2}$, S. Flazi ${ }^{1}$, Z. Khiat ${ }^{1}$ and Y. Kitamura ${ }^{3}$ \\ ${ }^{1}$ University of Science and Technology of Oran, USTO-MB, Algeria \\ BP 1505, EL M'Naouer, Oran (31000). Algeria. \\ Tel \& Fax: 00213415603 29/01. E-mail: stambouli@ssb-foundation.com \\ ${ }^{2}$ Graduate School of Frontier Science, University of Tokyo, Japan \\ ${ }^{3}$ Institute for Arab Economies Research, Japan
}

\begin{abstract}
In this contribution a particular attention is being given to the joint event that bring together the relevant parties, University of Sciences and Technology of Oran (USTO-MB), six Japanese Universities, Japan International Corporation Agency (JICA), Japan Science and Technology Agency (JSTA), University of Saida and the URER/MS Renewable Energy Centre of Adrar to develop a long-term vision and strategy to boost the ideas for the realisation and the development of the Sahara Solar Breeder (SSB) project. The Science Council of Japan (SCJ) proposed the SSB plan at the G8+5 Academies' meeting in Rome in 2009, and appealed for international cooperation to solve the global energy and ecological issues [1]. The SSB plan starts from basic material research on innovative solar Si technology (more than and beyond Siemens processes) and High critical Temperature Superconducting Cables $\left(\mathrm{HT}_{\mathrm{c}} \mathrm{SC}\right)$ for DC transmission in order to speed up the electric superhighway. The generated electricity from SSB, made up of a network of Very Large Scale-PV Power Systems in Sahara desert, will have to be transferred to the North Africa, then Europe, Africa, and ultimately the rest of the world, via $\mathrm{HT}_{\mathrm{c}} \mathrm{SC}$ that can provide, in compact dimension, firm capacity for base load, intermediate and peaking power, effectively complementing conventional electricity sources. Because $\mathrm{HT}_{\mathrm{c}} \mathrm{SC}$ are compact and can transmit a large amount of electric power (up to 10 times as much power as conventional electric power transmission cable), it can utilize more effectively congested underground space where a lot of piping and other units already exist. This project will also tackle the key challenges and issues related to the field of PV putting forward the USTO-MB perspective and promoting its R/D activities by a collaborative research plan between Japan and Algeria. In addition to the wellrecognized two values of vast land and sunshine, the desert of Algeria has the third value, sand, for its main component, $\mathrm{SiO}_{2}$.
\end{abstract}

\section{Keywords}

Sahara, silica sand, photovoltaic energy, environment, $\mathrm{HT}_{\mathrm{c}} \mathrm{SC}$

\section{Introduction}

The sun, a natural fusion reactor, is located far enough away to safely bring 10,000 times as much energy as we need to the earth. In principle, all the global energy demand could be afforded in the form of electricity by covering $4 \%$ of the world's desert surface with photovoltaic (PV) panels. Energy consumption in developed countries grows at a rate of approximately $1 \%$ per year, and that of developing countries, $5 \%$ per year. At present, the bulk of our energy comes from fossil fuels (gas, coal, and oil). These are hydrocarbons composed of hydrogen and carbon atoms which when combined with the oxygen in the air and heat, they react exothermically. Atmospheric and environmental pollution as a result of extensive fossil fuel exploitation in almost all human activities has led to some undesirable phenomena that have not been experienced before in known human history. Fossil fuel consumption continues to increase and emissions have increased dramatically over the past century in that, massive amount of carbon dioxide in the atmosphere has dire implications for the delicate balance of our ecosystem and could eventually lead to runaway climate change. Such phenomena are varied and include global warming and the greenhouse affect [2], ozone layer depletion, acid rain, hazardous air quality and water pollution, forest destruction and major environmental accidents. Present reserves of oil and natural gas can only cover consumption at this rate for the next 50 years in the case of oil, and for the next 70 years in the case of natural gas (figure1) $[3,4]$. Dependence on energy from fossil fuels is also reaching its limits. Therefore, one of the fundamental priorities for a country such as Algeria is to use several renewable energies (RE) sources and environmentally friendly energy conversion technologies. Algeria has the potential to be one of the major contributors in solar energy 
and become a role model to other countries in the world (figure 2) [5-8].

The serious disadvantage in PV, output power fluctuation depending on the time, climate, and location, could be overcome by global PV networking with a superconducting grid. SSB may be presumed to be a quixotic challenge, but it is the universal dream comes true if we can say "YES" for the following questions:

1. Can PV be superior to conventional energy sources judging from its quality, quantity, cost, and sustainability?

2. Is SSB feasible scientifically, technologically, and economically?

SSB is an Energy/Climate security with global justice and development of civilisation for whole world and a clever global development strategy for solving the energy and climate problems with existing solar grade Silicon production from Sahara sand technology for a world in a sustainable way.

\section{Sahara Solar Breeder, a new global climate policy}

The SSB plan involves building manufacturing plants around the Sahara desert that would extract silica from the sand and turn it into solar panels to generate RE. The RE from the first facility will then be used to breed more manufacturing plants and, in turn, more solar panels to generate ever increasing amounts of solar power (figure 3) $[1,9]$. SSB will then ensure an Energy/Climate security with global justice and development of civilisation for whole world, a clever global development strategy for solving the energy and climate problems with existing solar grade Silicon production from Sahara sand technology for a world in a sustainable way. Moreover, SSB is an integrated community, socio-economic, industrial, agricultural, environmental, and science and technology development solution. In particular, through desalination and adequate irrigation technologies, it will help mainstream marginal desert water resources and lands back into national, regional and international development processes [10].

The ultimate goal is to build enough plants until the breeding strategy can deliver $100 \mathrm{GW}$ of electricity to provide $50 \%$ of the world's electrical power generation capacity by 2050 which would be delivered via a global superconducting electrical grid to turn the world's biggest desert into the world's biggest power station taking advantage of two resources that are found in abundance in the Sahara namely silica and sunlight.

In August the $4^{\text {th }} 2010$, USTO-MB and JICA formed a joint group and signed a series of Memorandum Of Understanding and bilateral agreements to announce the creation of a Sahara Solar Energy Research Center (SSERC) to pursue the realisation and the development of PV plant at the chosen experimental site at the University of Saida in the south west of Algeria also known as the gate of the Algerian Sahara. SSB, is a project which proposes a plan of international partnership in basic research and development, industrial production, trade, financing, etc, to construct, gradually over the coming decades, a "Global Clean Energy Superhighway" starting in the Sahara desert in North Africa (beginning from Algeria). SSB will help migrate from the unsustainable current excessively fossil-fuel-based global energy paradigm to a more sustainable one. It will also help meet global energy challenges, and mitigate climate change and other environmental problems. SSB is more than an energy solution. It is an integrated community, socioeconomic, industrial, agricultural, environmental, and science and technology development solution. In particular, through desalination and adequate irrigation technologies, it will help mainstream marginal desert water resources and lands back into national, regional and international development processes. The concept of the SSB is depicted in figure $4[9,10]$.

\subsection{SSB plan and the SSERC activities}

The goals of SSB towards sustainable development are founded on four pillars namely:

- $\quad$ Starting from basic research and development;

- Coupling PV with High critical Temperature Superconducting Cables $\left(\mathrm{HT}_{\mathrm{c}} \mathrm{SC}\right)$ for clean energy generation and energy saving transmission;

- Education and training for science and technology of African people

- Solving global crisis by international cooperation and policy

The three basic strategies of the SSERC programs and indicative targets are based on the following items:

- Innovation processes for solar silicon with a focus on using Sahara sands, the following objectives have been selected:

$>$ Purification of silica sand by a thermodynamics based process designed in Tokyo and Nihon universities

$>$ Reduction of silica sand by carbothermal (Hirosaki University) and plasma (NIMS) processes

$>$ Technology transfer to USTO

- Quantitative data collection for installation of PV and $\mathrm{HT}_{\mathrm{c}} \mathrm{SC}$ systems, the following objectives have been selected:

$>$ PV system installation at Saida site

$>$ Data collection for DC power transmission trough desert environment

- Education and training on Energy problems and sustainable development, the following objectives have been selected:

> Installation of WebEl system at USTO and Saida universities

$>$ Development of PV materials devices and system

$>$ PV application such as desalination, green innovation in desert

$>$ Personal movement between Algeria and Japan 


\subsection{Sahara Solar Breeder components}

The most important objectives of SSB's energy policy and its portfolio include five basic strategies that are:

$>$ Basic, applied, practical research and development, in Japan, North Africa, the Middle East, Africa, and other regions of the world;

$>$ Industrial production of silicon from sand;

$>$ Industrial production of cells, modules, panels, and other PV devices,

$>$ Building, operating, networking and monitoring Very Large Scale Photovoltaic Power Stations (VLS-PVPS);

$>$ Environment monitoring and gradual implementation of SSB

One of the strengths of PV is to be found in its decentralised applications. This is particularly true for supplying isolated consumers in areas of low population density, where the demand consists essentially in satisfying basic energy requirements. Other notable characteristics of PV are:

- Modular design enabling it to be extended according to need;

- The possibility of developing small businesses in areas of low economic development;

- Protection of the environment;

- Limited capital assets, capable of being used flexibly and in a decentralised way, and of being moved about over longer periods of time.

The developing strategy, by the SSB project, has been elaborated to promote the dissemination of RE on sites where they are profitable compared to classical energies and to guide scientific research efforts in order to allow generalisation of RE via mass production. The aims to be achieved consist of the contribution to a conservative policy for hydrocarbons both by increasing the RE share within the international energy balance and by improving the living conditions of isolated communities. The first operation of installation of PV plant in Saida town, considered to be the gate of the Algerian Sahara, would allow on one hand the electricity supply and on the other hand to collect information about:

- Equipment behaviour in Saharan environment;

- Matching the systems with the electricity supply;

- Maintenance of organisation and management;

- Technical -economic system optimisation.

\subsection{High critical temperature superconducting cables for DC electric transmission from SSB PV power plant}

The demand for power keeps growing at a scale and speed never imagined in the past since the need for more and more electricity is exacerbated. Moreover, demanding economic objectives as well as obligations to reduce greenhouse gases made a strong push for renewable energy sources (RES) with power generation becoming increasingly distributed and a growing number of generation facilities located far away from load centers. This situation has stimulated research on DC electric power transmission systems that are able to transport large amounts of electrical power, in contrast with the more common alternating current systems. For long-distance distribution, DC power systems present lower capital costs and suffer lower electrical losses. They are poised to help to reduce grid congestion as well as installation and operating costs. In addition, $\mathrm{HT}_{\mathrm{c}} \mathrm{SC}$, using an $\mathrm{N}_{2}$ cooling system (figure 5) [11], are characterized by the following advantages:

(1) Compactness and high transmission capacity;

(2) Low transmission loss and environmental friendliness;

(3) No leakage of electro-magnetic field to the outside of the cable;

(4) Low Impedance and Operatability; and

(5) Effectuate transportation of solar-generated power from the Sahara.

\section{SSB roadmap}

The objectives established for the SSB project are focused on raising PV production every 10 years for a global superhighway purpose. Crucial objectives are targeted at substantially increasing and enhancing PV production from an initial value of $2 \mathrm{MW}$ to breed into $100 \mathrm{GW}$ in 30 years. Although various semiconductors are available for PV, we can deduce that $100 \mathrm{GW}$ annual solar cell productions is the minimum requirement for covering more than $30 \%$ of global energy needs and that only Si can clear this hurdle (table1). Tentative specification and roadmap of SSB plan are outlined in table 2. The electrical power will be obtained from Si based solar PV power plants. By assuming two years energy payback time, solar cell production can be doubled every two years to increase $2 \mathrm{MW}$ PV to $100 \mathrm{GW}$ in 30 years as depicted in table 3 .

\section{Conclusion}

Clean and secure energy is the key to a sustainable civilization, key to human security, key to a reliable energy supply, key to climate stability and bio-diversity, key for global and inter-generational justice and a key to more civilization and wealth. SSB ensures Energy/Climate security with global justice and development of civilisation for whole world. It has a clever global development strategy for solving the energy and climate problems with existing solar grade Silicon production from Sahara sand technology for a world in a sustainable way [12]. SSB also seeks to identify the most important challenges facing both the research and economic sectors and put forward new strategies that will identify the required skills to transform the research prospects of USTO-MB based on the analysis and prospect of elementary processes and system design. (SSB foundation: www.ssb-foundation.com)

\section{References}

[1] H. Koinuma, I. Kanazawa, H. Karaki, K. Kitazawa: SCJ proposal @G8+5 Academies' meeting (Rome, Mar. 26, 2009)

[2] International Energy Agency (IEA) 2009. http://www.iea.org 
[3] H. Ezzeldin, "Global energy challenges \& sustainable energy. Shell overview" International conference on sustainable energy, Technologies, Materials \& Environmental Issues Oct., 29 - Nov.1st, 2007. Cairo, Egypt

[4] United Nations, World population Prospect, the 1998 revision and estimates by the population reference Bureau.

[5] Wuppertal Institute for climate, Environment and Energy and the CREAD, Algeria- a future supplier of electricity from renewable energies for Europe?

[6] Renewable Energies Development Centre. www.cder.dz

[7] Boudghene Stambouli A., 2007. Survey report on "Renewable Energy Manufacturing Facilities in Algeria" United Nations, Index 382958

[8] A. Boudghene Stambouli, Z. Khiat, S. Flazi and Y; Kitamura, A review on the renewable energy development in Algeria: Current perspective, energy scenario and sustainability issues. Renewable and Sustainable Energy Reviews, Volume 16, Issue 7, (2012), Pages 4445-4460,
[9] Energy from the desert- III": IEA-PVPS Task-8 Report, ed. by K. Kurokawa et al., James \& James Ltd., UK (2009)

[10] H. Koinuma, K.Kurokawa, K.Kitazawa, H.Fujioka, M.Sumiya, Y.Furuya, K.Itaka, T.Hashimoto, S.Yamaguchi, J.Shimoyama, A Stambouli and N.Benharrats, Oxide initiative to make the dream of 'Sahara Solar Breeder Plan' come true. 17th Int'l Workshop on Oxide Electronics, WOE17 Abst. 100530. Awajishima, Japan

[11] Takato MASUDA et al, High-temperature Superconducting Cable Technology and Development Trends. SEI Technical Review, $\mathrm{N}^{\circ} 59$, January 2005

[12] A. Boudghene Stambouli and H. Koinuma, A primary study on a long-term vision and strategy for the realisation and the development of the Sahara Solar Breeder project in Algeria. Renewable and Sustainable Energy Reviews 16 (2012) 591598

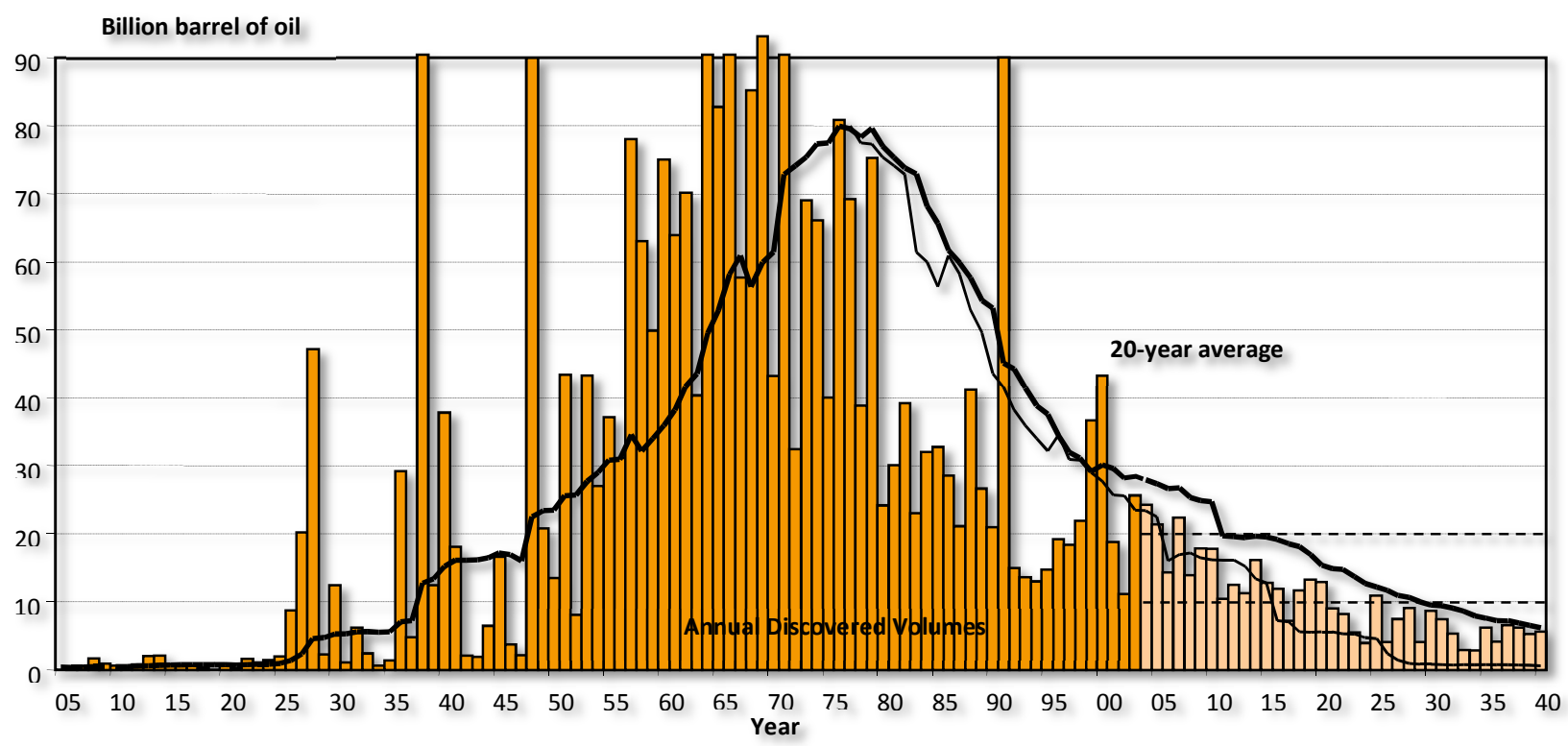

Figure 1: Confronting the supply challenges, annual discovered volume of oil (1905-2040)
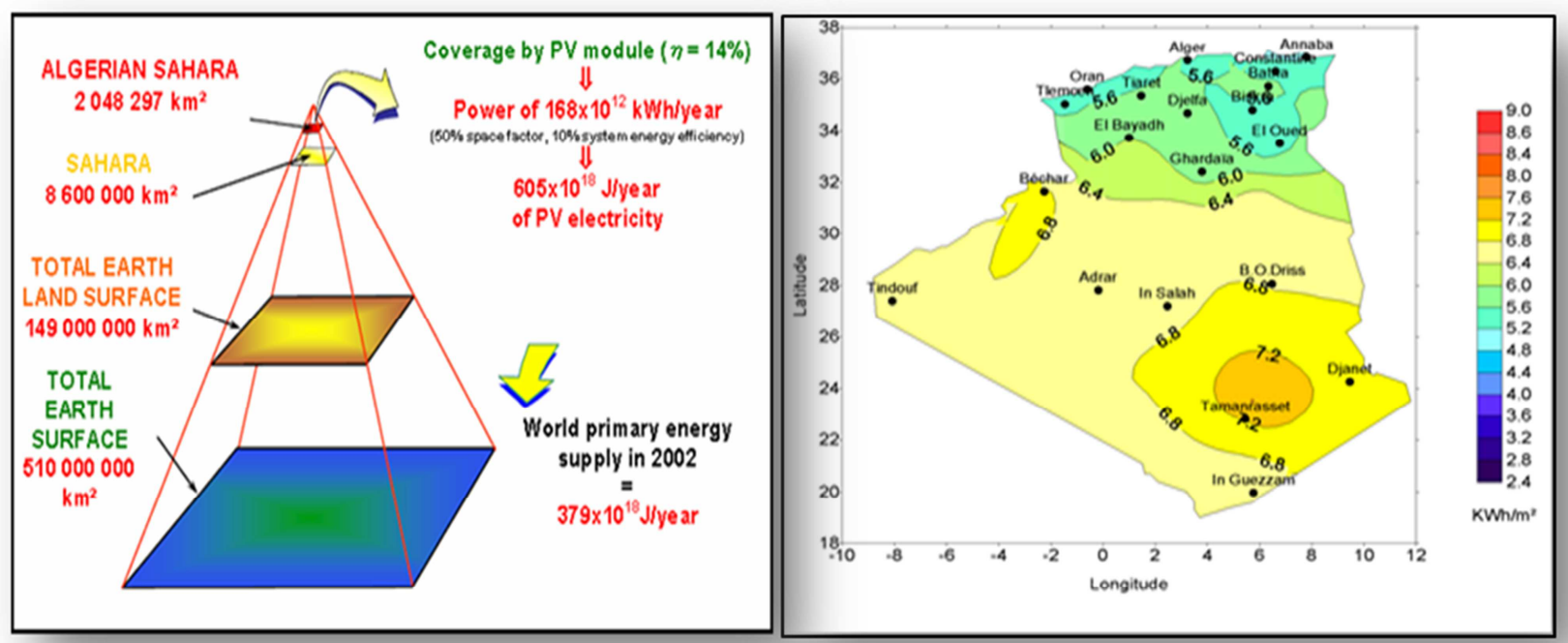

Figure 2: Solar pyramid and Potential sites, the Algerian desert, dead space can be a treasure island of energy used by humanity 


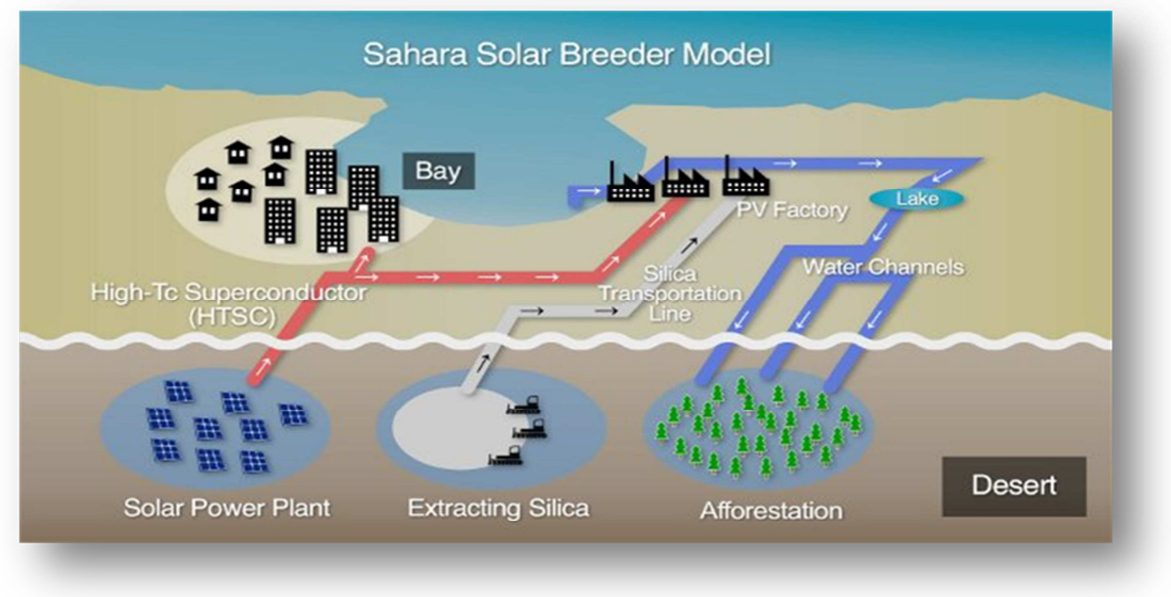

Figure 3: SSB model, key to a sustainable civilization
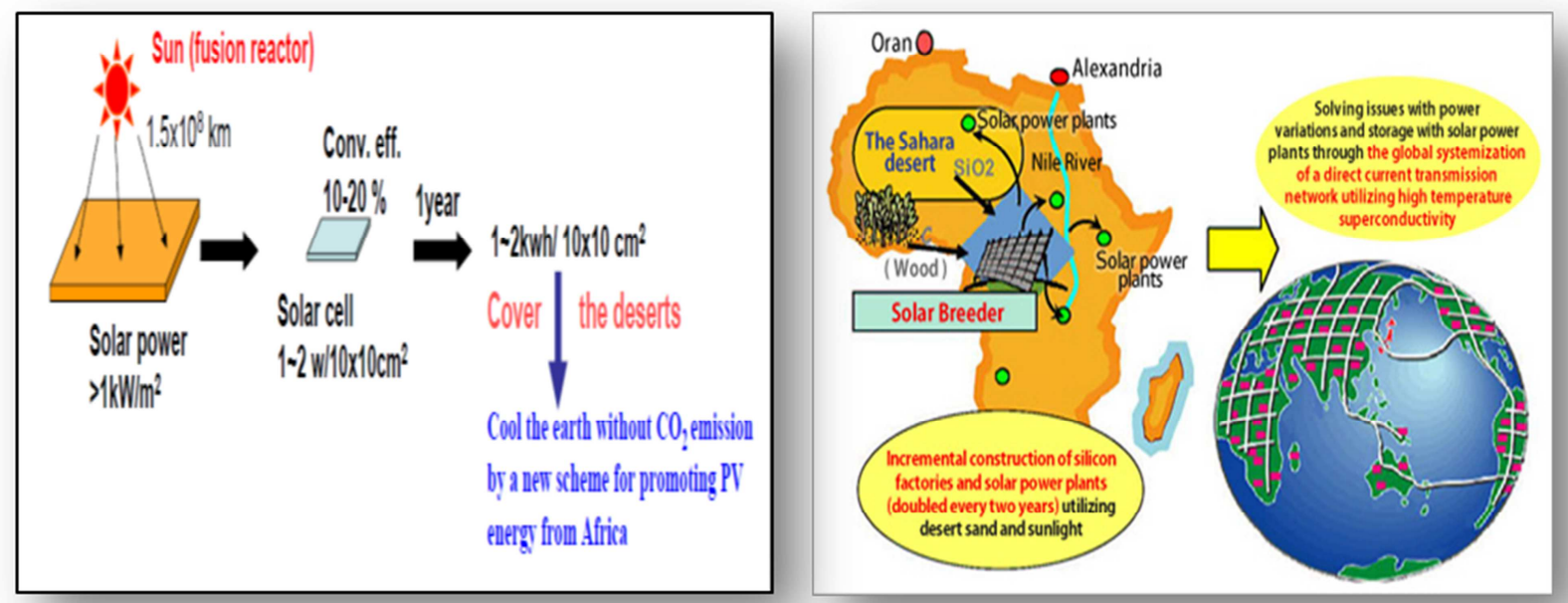

Figure 4: SSB concept and plan
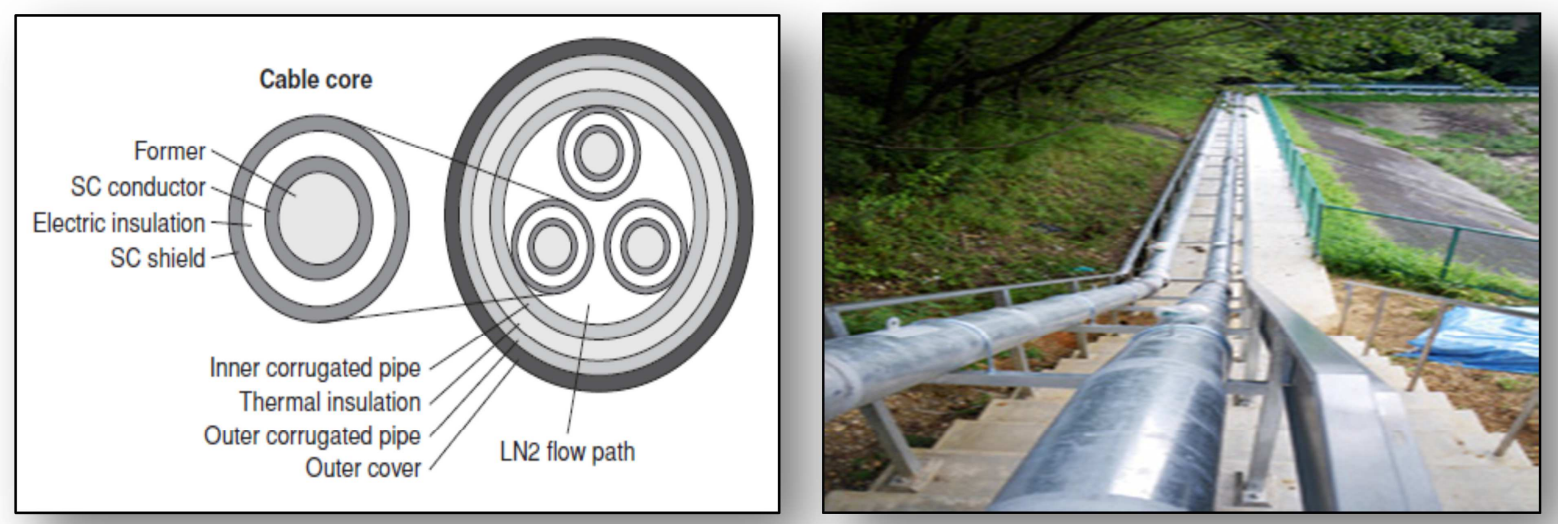

Figure 5: Structure of $\mathrm{HT}_{\mathrm{c}} \mathrm{SC}$ cable (experimental 200 meters completed new line, first of its kind in the world) 
Table 1: Solar cell materials and power generation capability, W: Wafer, TF: Thin Film (Evaluated from material needs, efficiency, and natural resources)

\begin{tabular}{|c|c|c|c|c|c|c|c|}
\hline Material & Type & $\begin{array}{c}\text { Thickness } \\
(\mu \mathrm{m})\end{array}$ & $\begin{array}{r}\text { Conversion } \\
\text { efficiency \% }\end{array}$ & Element & Wp/g & $\begin{array}{c}\text { Ressouce } \\
\left(10^{3}\right. \\
\text { tonne })\end{array}$ & $\begin{array}{c}\text { Capability of } \\
\text { power } \\
\text { generation }(\mathbf{G W})\end{array}$ \\
\hline \multirow[t]{2}{*}{ c-Si } & W & 200 & 20 & $\mathrm{Si}$ & 0.10 & $\infty$ & $\infty$ \\
\hline & $\mathrm{TF}$ & 20 & 15 & - & 0.75 & $\infty$ & $\infty$ \\
\hline $\mathbf{a}-\mathbf{S i}$ & $\mathrm{TF}$ & 0.7 & 10 & $\mathrm{Si}(\mathrm{H})$ & 19 & $\infty$ & $\infty$ \\
\hline \multirow[t]{2}{*}{ InP } & $\mathrm{W}$ & 200 & 25 & In & 0.33 & 1.68 & 0.56 \\
\hline & $\mathrm{TF}$ & 2 & 20 & - & 26 & - & 44.5 \\
\hline \multirow[t]{2}{*}{ GaAs } & W & 200 & 25 & $\mathrm{Ga}(\mathrm{As})$ & 0.49 & 110 & 53.9 \\
\hline & $\mathrm{TF}$ & 2 & 20 & & 39 & - & 4,310 \\
\hline \multirow[t]{2}{*}{ CuInSe2 } & $\mathrm{TF}$ & 2 & 15 & In $(\mathrm{Cu})$ & 38 & 1.63 & 64 \\
\hline & & & & & 28 & 83 & 2,290 \\
\hline \multirow[t]{2}{*}{ CdTe } & $\mathrm{TF}$ & 2 & 15 & $\mathrm{Cd}$ & 27 & 555 & 15,100 \\
\hline & & & & $\mathrm{Te}$ & 24 & 22 & 526 \\
\hline \multirow[t]{2}{*}{ Ge } & W & 200 & 15 & $\mathrm{Ge}$ & 0.14 & 4.4 & 0.62 \\
\hline & $\mathrm{TF}$ & 0.5 & 15 & - & 60 & - & 250 \\
\hline
\end{tabular}

Table 2: Roadmap of SSB road and global energy superhighway

\begin{tabular}{|c|c|c|c|c|}
\hline $\begin{array}{l}\text { Year } \\
2009\end{array}$ & 2010 & 2020 & 2030 & $2040-2050$ \\
\hline Planning & $\begin{array}{l}\text { Master plan } \\
\text { First }\end{array}$ & Second & Third & $\begin{array}{l}\text { Global energy } \\
\text { highway Final }\end{array}$ \\
\hline $\begin{array}{l}\text { SSB } \\
\text { construction }\end{array}$ & $\begin{array}{l}\text { First term } \\
2 \rightarrow 16 \text { MW PV station } \\
\text { Si \& cell factory } \\
\text { HT }_{c} \text { SC transmission line } \\
\text { test station }\end{array}$ & $\begin{array}{l}\text { Second term } \\
32 \rightarrow 512 \mathrm{MW}\end{array}$ & $\begin{array}{l}\text { Third term } \\
1 \mathrm{GW} \rightarrow 16 \mathrm{GW} \\
\text { Extension of SSB to } \\
\text { continents }\end{array}$ & $\begin{array}{l}\text { Fourth term } \\
32 \rightarrow 512 \mathrm{GW} \\
\text { Extension of SSB to } \\
\text { the world }\end{array}$ \\
\hline $\begin{array}{l}\text { Management } \\
\& \\
\text { finance }\end{array}$ & $\begin{array}{l}\text { International cooperation } \\
\text { Sahara clean energy } \\
\text { consortium }\end{array}$ & & $\begin{array}{l}\text { Continental clean energy } \\
\text { consortium }\end{array}$ & $\begin{array}{l}\text { Global clean energy } \\
\text { consortium }\end{array}$ \\
\hline
\end{tabular}

Table 3: Evolution of PV solar cell production

\begin{tabular}{|c|c|c|c|c|}
\hline Starting date 2012 & 2014 & $2012+n$ & 2030 & 2044 \\
\hline $2 \mathrm{MW}$ PV power station made from $\mathrm{Si}$ (20 tons) & $\begin{array}{l}+1=\text { total } 2 \\
\rightarrow 4 \mathrm{MW}\end{array}$ & $\begin{array}{l}\text { Total }=2^{\mathrm{n} / 2} \\
\rightarrow 64 \mathrm{MW}\end{array}$ & $\rightarrow 1 \mathrm{GW}$ & $\rightarrow>100 \mathrm{GW}$ \\
\hline Si plant (10tons/year) & +1 & $+2^{\mathrm{n} / 2}-1$ & & \\
\hline p-Si cell Plant & +1 & $+2^{n / 2}-1$ & & \\
\hline
\end{tabular}

